\title{
THE IMPACT OF EU STATE-BUILDING POLICIES ON THE DEMOCRATIZATION PROCESS IN MACEDONIA - A REALIST ANALYSIS
}

\author{
Adrian Waters ${ }^{1}$ \\ LUISS Guido Carli, Rome
}

\begin{abstract}
From the early 2000s onwards the EU has embarked on becoming a major state-building actor in the Balkans so that the countries in the region could establish functioning democratic institutions and eventually become member states themselves. One such country is Macedonia, which has so far experienced various stages of state-building involving intervention from the EU in its domestic affairs. This research article assesses the impact of EU state-building policies on its democratisation process from the republic's independence in 1991 to the present day, after its constitutional name was changed to North Macedonia. In order to do so, it examines the three different phases of EU state-building in Macedonia (1991-2001, 2001-2015, 2015-today) using realism as a theoretical approach to analyse events, trends and how the EU and the Macedonian political leadership interact with each other. The findings reveal that the EU's line towards the young state was mainly shaped by security and geopolitical interests rather than normative or idealistic concepts of European integration. Macedonia's behaviour can be described as an example of bandwagoning, i.e. aligning with the stronger powers as a means of acquiring benefits. However, the findings of this article suggest that Macedonia has not gained any substantial advantages from its alignment with the EU. This has resulted in a democratic backsliding that turned the country into a hybrid regime which currently does not have a realistic accession prospect due to disputes imposed by its neighbours and differences among EU member states about the future of enlargement.
\end{abstract}

Keywords: European Union, state-building, realism, Macedonia, democratisation.

\section{Introduction}

State-building has been a notable feature of the EU's foreign policy towards candidate countries in the Balkan region since the early 2000s (Bieber, 2011a). The aim of this procedure was to create functioning states that would be able to deliver what their citizens want and become fully-fledged members of the Union. Beyond the idealistic and normative notions that are presented as the driving forces of EU enlargement in the Balkans, there are also reasons linked to the security and geopolitical interests of certain member states that determine the organisation's conduct towards countries that were going through their own individual processes of state-building. One of these was North Macedonia (from here after Macedonia), which has

${ }^{1}$ Contact address: adrianw.waters11@gmail.com 
endured a significant amount of foreign intervention in its internal affairs, particularly from the EU which has turned into a key state-building actor through its conditionality and enlargement policy mechanisms (Vankovska, 2020). The democratisation process in Macedonia was severely affected by these policies. Although they initially contributed to the republic's improvement in democratic standards, a period of stagnation ultimately resulted in backsliding to the point that the country is now considered to be a hybrid regime. The purpose of this research article will be to assess the impact of the EU state-building policies on the democratisation process in Macedonia from the onset of independence in 1991 to the present day. Realism will be used as a theoretical approach in order to interpret the ways in which the EU and Macedonian politicians behaved towards each other.

The three sections of this paper will describe the phases of EU state-building in Macedonia. The first one will look at the country's attempt at building a liberal democracy with limited input from the EU between 1991 and the dawn of the new millenium. The second will focus on the 2001 conflict and how the Union, allied with the US, imposed an ethnic power-sharing arrangement via the Ohrid Framework Agreement, allowing these two powers to influence Macedonia's domestic matters. Lastly, while taking into consideration the contemporary European geopolitical scene, the third section will survey the effects of the 2015 Pržino and 2018 Prespa Agreements on the Macedonian political system and how the country's democratic standards regressed. Combined with a realist analysis, this piece will aim to provide a different viewpoint on how the EU works, especially in its dealings with candidate countries.

\section{Early stage of state-building in Macedonia (1991-2001)}

The first stage of state-building in Macedonia was between 1991, when it obtained independence from Yugoslavia, and 2001. In this period Macedonian political elites "uncritically embraced the Western model of liberal democracy" (Vankovska, 2012:26). The democratisation process began in 1990 when the country's first democratic elections were held with no party having a majority in the 120-seat parliament. In early 1991 Kiro Glirov was chosen as president of the republic. He succeeded in forming a government of experts comprising all parliamentary parties. Later in September, an independence referendum was held with a turnout of 72.16 per cent and with 95.08 per cent of the voters in favour of an independent Macedonia, which became a reality two months afterwards (Daskalovski, 1999; Rossos, 2008).

The government of experts did not last long. In August 1992 the Social Democrats (SDSM) succeeded in forming the first political government in post-independence Macedonia (Pankovski et al, 2020). Far from being democratic, SDSM led a competitive authoritarian regime which persecuted opposition activists and maintained strict control over public and some private media outlets. State radio and televisions monopolised national broadcasting and in 1995 more than 80 private radio and TV stations were forcibly closed down. Apart from the 1998 parliamentary elections, won by the conservative party VMRO-DPMNE, Macedonian elections until 2000 were mostly marked by irregularities (Gromes, 2009; Levitsky \& Way, 2010; Pankovski \& Mladenovska, 
2019; Pankovski et al, 2020). So for this period Macedonia was classified as a persistent hybrid regime (Morlino, 2009).

In post-communist countries ruled by authoritarian parties and undergoing a transition period, non-democratic practices from the previous regime were expanded with new ways of abusing power. The parties that set the new institutional rules and privatised publicly owned capital took advantage of the situation in order to amass power and riches. This was the case in Macedonia where the democratisation process of the 1990s took place in the context of low economic viability levels and high unemployment (reaching 35.69 percent by 1995) due to the privatisation measures implemented under the diktat of the International Monetary Fund (IMF) and the World Bank. The managers of public enterprises linked to SDSM benefitted from these policies and were considered to be the party's key sponsors. This trend continued during the first VMRO-DPMNE administration when individuals and businessmen tied to them also profited from it. The transition period in Macedonia unleashed a condition of full state capture where the ruling parties employed party members as civil servants, thus subjugating the institutions that are supposed to control their conduct (Saveska \& Brown, 1999; Siljanovska-Davkova, 2013; Stambolieva, 2013; Cjuzelov \& Hadjievska, 2020).

Apart from issues related to democratisation, Macedonia's early state-building efforts had to tackle the demands of its biggest ethnic minority, the Albanians, comprising 23 percent of the population according to the 1994 census. The republic's foundations were not fully backed by the Macedonian Albanians as evidenced by the fact that they boycotted the independence referendum (Daskalovski, 2004). Nevertheless, inter-ethnic relations were spared complete deterioration by a process of legislative and executive power-sharing ensuring that non-discriminatory policies were adopted. Government and party leaders also intervened during critical moments to deter escalations via moderate voices and diplomatic actions (Lund, 2000). For almost a decade Macedonia was the only multi-ethnic post-Yugoslav republic to avoid ethnic cleansing and be led by interethnic administrations which was a stabilising factor at a time when most Balkan governments were nationalist and exclusionary. However, political cooperation between the two communities was overshadowed by the fact that society remained divided on ethnic lines, with mistrust and limited dialogue between both sides. At a political level, parties remained ethnically distinct and their relations were defined by patronage systems and catering only to their respective ethnic groups (Berg \& van Meurs, 2002; Holliday, 2005; Bieber, 2020).

The EU's involvement in Macedonian politics was limited during this early state-building phase. Initially, the Union could not recognise the newly-independent Macedonian republic due to Greek objections. In order to ensure that Greece ratified the Maastricht Treaty, official recognition was only possible after the agreement came into effect and following Macedonia's admission to the UN under the provisional title FYROM (Wydra, 2020). By 1995 the Union had abandoned its unanimous support for Greece in its dispute with Macedonia. Firstly, because Kiro Gligorov strove for ample EU involvement. Secondly, when Greece started an embargo on Macedonia, many member states, particularly Germany, Italy and the Netherlands, opposed this move because they considered it needlessly antagonistic and called for dialogue. Later, the Union 
sued Greece at the European Court of Justice (ECJ) stating that the embargo contradicted EU law. This lawsuit was withdrawn after Greece signed an Interim Accord with Macedonia. Afterwards, the EU affirmed that the name dispute was simply a bilateral affair and initiated full diplomatic relations with Macedonia in December 1995, leading to increased ties between the two. The efficacy of EU diplomacy was hindered by a disparity of power among member states, the absence of a common foreign and security policy and Union solidarity as well as the inability of the EU to behave as a neutral arbiter (Ilievski \& Taleski, 2009). Realists would say that it was clear even from the early days of the EU that close political and economic unity would not prevent member states acting along national lines and violating the rules. In fact, many EU countries often seem to behave unilaterally to pursue their own national interests, sometimes at the expense of fellow members, which is partially why the Union has yet to devise a collective foreign and security policy (Mearsheimer, 2010).

There are elements of realism in the reasons why Macedonia's first president Gligorov wanted his country to engage with the EU. He had a traditional understanding of international relations, based on ideas linked to balance of power, the search for security in the world arena and the awareness that small countries need to depend on international institutions to safeguard their interests and security. The context in which he was working justified his realist foreign policy approach since he regarded the EU and NATO as means of guaranteeing regional peace and security and rarely advocated Macedonia's entry into these organisations because of democratic norms and values (Koneska, 2014).

It would be useful to elaborate why the EU had its own reasons for getting involved in the Western Balkans after 1991, reasons which proved to deeply concern Macedonia. The region had long been of strategic concern for the Union in political and security terms, especially with regards to political stabilisation and peace-building. Apart from democracy promotion, the EU pursued various security priorities from post-conflict rehabilitation to state-building among other things (Richter, 2012). During the late 1990s, the member states had these objectives: stabilising the newly-emerging democracies in Eastern Europe; consolidating market economies in the region; and ensuring that these countries participated in the integration processes of organisations such as the EU and NATO and in the creation of a new system of international relations (Fassino, 1997). In this scenario the Balkans were supposed to be anchored to the EU to prevent it from becoming an area of instability at the dawn of the 21st century (Dini, 1997). From a realist viewpoint, the EU is a tool for member states to jointly shape the regional environment. This role developed as a response to the structural changes prompted by the collapse of Cold War bipolarity (Hyde-Price, 2008). The Yugoslav wars and the ensuing instability and refugee crises rendered the Western Balkans the focus of EU member state interests, particularly Germany, whose involvement in the 1999 Kosovo war showed that it had a security interest in bolstering stability in the region (Cavoski, 2015).

Although interactions between the EU and Macedonia were limited in the latter's early phase of state-building, it was clear that the former would soon play a major role in the democratisation process. 
From 1992 onwards, Brussels gave financial assistance to Macedonia for the development of democracy and a free-market economy (Pond, 2006). Indeed, EU engagement impacted the country's regime trajectory. A broad pro-EU consensus rose and so government and opposition parties increasingly abided by regional norms. For instance, SDSM allowed greater international observation of elections in the late 1990 s to ameliorate their fairness and quality. While both SDSM and VMRO-DPMNE ruled in an authoritarian way in this period their consolidation of power was restricted by "state weakness and the accelerating process of European integration" (Levitsky \& Way, 2010:126). At the Zagreb conference in November 2000, Brussels and Skopje initialled the first Stabilisation and Association Agreement (SAA). However, this was a reward for constraining the potential for inter-ethnic strife rather than for the political and economic reforms that had been implemented. At this point, the Union's conditionality failed to resolve ethnic disputes since it was overpowered by regional stability considerations (Berg \& van Meurs, 2002). It was only the outbreak of ethnic violence in 2001 that turned Macedonia into a top concern for EU foreign policy (Ilievski \& Taleski, 2009).

\section{The second stage of state-building in Macedonia (2001-2015)}

The second phase of state-building in Macedonia happened in the aftermath of the 2001 insurgency when Western state-builders "uncritically applied a power-sharing medicine" in the form of the Ohrid Framework Agreement (Vankovska, 2012:26).

NATO's intervention against Yugoslavia in 1999 over Kosovo set the scene for the subsequent conflict in Macedonia and strengthened the Kosovo Liberation Army (KLA)'s Greater Albanian expansionist agenda (Carpenter, 2002). There were Macedonian Albanians within the KLA, including Ali Ahmeti who later became leader of the Macedonian offshoot, the National Liberation Army (NLA). In January 2001 an insurgency began that saw the NLA fighting the Macedonian security forces. The conflict lasted until August of the same year and did not bring ultimate victory to either side (Rossos, 2008; Gromes, 2009; Dimitrov, 2011).

Though initially reluctant to interfere in another Balkan conflict, the EU, NATO and the USA were soon involved in order to apply "enough pressure and incentives to convince Albanian and Macedonian elites that their best interest would be found in a negotiated settlement" (Hislope, 2003:130). Because of diminishing American activity, the hostilities in Macedonia allowed the EU to take a decisive role (Dimitrov, 2011). Hence, "the international community, with the EU in a leading role, acted promptly since a civil war or even the disintegration of the Macedonian state might reduce all its efforts in stabilizing the region to naught" (Berg \& van Meurs, 2002:62). Moreover, the Union had developed its own Common Security and Defence Policy (CSDP) as a response to its previous failures in the Balkans and thus wanted to put it into practice. Furthermore, recent history proved that any war in the region could strain the Atlantic alliance, and so both the US and the EU had interests in ensuring that Macedonia's problems did not worsen. Lastly, since Bulgaria and Greece held historical disagreements with Macedonia, there were fears that the crisis would foster a regional contest that might involve dividing the country. The US and the EU wanted to avoid a partition of Macedonia or anywhere in the Balkans (Dobbins et al, 2008). This 
case corroborates the theory of defensive realists who "view the CSDP as a way of participating in an American-led division of regional labour" (Howorth, 2014:194) and consequently "as a vehicle for keeping America engaged in the Euro-Atlantic region" (Rynning, 2011:37).

At the onset of the fighting, high-ranking EU and NATO officials, such as Javier Solana who was the EU High Representative for Common Foreign and Security Policy, displayed unconditional support to Skopje. Accordingly, Macedonia became the first Balkan country to conclude a Stabilisation and Association Agreement in April 2001 as an incentive to find a peaceful solution to the violence. However, seeing that neither side was winning, the EU and NATO pressured the Macedonian government into signing the Ohrid Framework Agreement (OFA) in August, with the two powers as guarantors of the deal. This document entailed moves towards decentralisation, the use of Albanian as a second language in Albanian-dominated municipalities and a parliamentary double majority vote required for certain issues, e.g. education, that has allowed Albanian parties to block legislative decision-making (Pond, 2006; Chivvis, 2008; Gromes, 2009). The 2001 crisis showed the Union's ability as a crisis management actor in cooperation with the US, especially with their use of the carrot of EU and NATO membership to induce political changes (Dobbins et al, 2008). Threats also proved to be useful. For example, in late June when the Macedonian army was confronting an NLA unit in Aračinovo, a town six miles away from Skopje, Chris Patten, the EU commissioner for foreign affairs, threatened to retain all aid from the SAA. The Macedonians gave in and allowed the safe passage of the NLA rebels (Hislope, 2003). The 2001 crisis forced the EU to alter its strategy to satisfy its own security interests coupled with the desire to stabilise Macedonia and improve its state structure (Richter, 2012).

The EU's success was also facilitated by the fact that Macedonian political elites attached more importance to European integration and economic support than nationalist programmes. International peacemaking efforts were fruitful partly because Macedonia was politically and economically too weak to withstand foreign pressure. Its risk-averse politicians positioned global standing above a resolute ethnic hegemony and a reckless armed struggle (Hislope, 2003). The 2001 conflict and the possibility of intervention from abroad raised doubts about the Macedonian state's ability to preserve its sovereignty. This helped to bolster the political leadership's resolve to join the EU and NATO because membership of these organisations were regarded as an additional, external warrant of the country's integrity and sovereignty (Koneska, 2014). Macedonian politicians thus accepted the Ohrid Agreement because EU and NATO representatives highlighted that only the implementation of such an agreement "would keep the popular prospect of Euro-Atlantic integration alive" (Gromes, 2009:24). From a realist perspective it can be said that weaker states have a tendency "to seek regional accommodation with the local hegemon in the hope of receiving special rewards" (Hurrell, 1995:343). In neorealist theory this is known as bandwagoning and it usually happens when there are power inequalities, when there are not many alternatives to accommodating a hegemon, and when a small state is geographically close to it. Although induced by real or potential threats, such strategy can provide material advantages to a smaller state (Ibid). Classical realism can also give insights into bandwagoning, especially because it is applicable to EU enlargement. This process can be defined as a wave-of-the-future 
bandwagoning which is when states bandwagon with the stronger side because it represents the wave of the future and are enticed by the profits of its prevailing ideology. An example is how post-communist states turned into liberal democracies. Consequently, candidate countries like Macedonia, want to enter the EU because they believe that they will participate in a more successful and prosperous endeavour (Schweller, 1994; Rynning, 2005). Additionally, as every government in Macedonia has been unable to provide what the public needs, their aspiration to achieve Euro-Atlantic integration is based on the pretext that it would foster economic growth, general well-being and foreign investment (Vankovska, 2018). In this regard, the aim of the OFA was not only to secure the future of Macedonian democracy but also to bring the country closer to the EU and NATO (Gromes, 2009).

The OFA was seen as a major triumph, especially by outsiders, because it ended the 2001 crisis before it morphed into a full-blown civil war and has maintained the multiethnic and unitary character of the Macedonian state (Bieber, 2011b; Rosülek, 2011; Crowther, 2017). However, despite its benevolent aims and supposed success in mitigating inter-ethnic tensions, the EU's state-building efforts via the Ohrid Agreement has arguably more defects than advantages. Firstly, it has failed to unite the Macedonian and Albanian communities because the constitutional changes institutionalised and entrenched ethnic divisions in society. Secondly, the Agreement has not improved Macedonian democracy and has replaced the pre-2001 unsuccessful transition with the rules of a semi-protectorate where the EU and US subtly interfere in the legislative, executive and judicial spheres of power to ensure the system works. With regards to legislation, their consent to draft laws is often more important than public and expert opinion. In terms of the executive, Brussels and Washington have participated in government-formation since 2001, although their influence has been limited after the 2006 parliamentary elections (Vankovska, 2013). These factors reinforce the argument that "liberal Western interventions contribute to the creation of 'governance states' in which the distinction between the internal and the external is extremely blurred" (Bliesemann de Guevara, 2010:121).

The EU's approach towards Macedonia at this stage was based on security interests. In the early 2000s the Balkans were still considered a likely threat to European security and this has influenced the policies of the member states ever since. In addition, the effect of the conflicts impacting many countries at the time motivated the EU to take steps that would safeguard the stability of existing and future member states (Cavoski, 2015). Indeed the EU has been criticised for preferring "stability over democracy...in countries that are of economic or security importance" (Babayan \& Risse, 2017:225). In the case of Macedonia, the ethos of the OFA was shaped more by security concerns than by democratisation aims (Richter, 2012).

From 2001 until 2005 Brussels was capable of exerting pressure on Macedonian politicians via its conditionality, based on the application of the OFA. Irrespective of the country's democratic status, the Union concentrated on the mediation and implementation of the Agreement, fearing that otherwise it would risk an escalation that might require the deployment of troops. The fact that security issues overwhelmed the conditionality policy was evident in 2005 when Macedonia was granted candidate status as a reward for enforcing the OFA and stabilising itself. Even though 
the European Commission criticised the country's lack of reforms, the European Council made this decision because of security reasons, as the member states were concerned that if they did not, then there would have been destabilising implications for Macedonia. Between 2005 and 2009, after certain important laws specified by the OFA were adopted, the EU's conditionality focused on the fulfilment of the Copenhagen criteria, particularly its democratic requirements. In 2009 the European Commission recommended that Macedonia should begin accession talks to reward its reforms. This recommendation was repeated in 2010 and 2011 notwithstanding a deteriorating political situation in Macedonia and in the region, including Kosovo's unresolved status dilemma, implying that security interests became significant again (Ibid). In this stage of state-building Macedonian politicians were receptive towards EU incentives since they regarded them as beneficial due to perceptions that they bolstered collective aims linked to autonomy for the Albanians and security for the Macedonians (Vasilev, 2011). Hence, Macedonian elites were responsive to EU pressure when they could perceive the advantages of reforms. However, the Union's elusive declarations and inability to offer realistic expectations of accession due to internal political tensions have caused stagnation in the country's democratisation process (Mihaila, 2012).

\section{The third and current stage of state-building in Macedonia (2015-present)}

The third and current phase of state-building in Macedonia arguably began in 2015 when the country's democratisation process went into crisis and was soon shaped by the Pržino and Prespa Agreements.

In January 2015 the VMRO-DPMNE prime minister Nikola Gruevski revealed that he had met with Zoran Zaev, the opposition SDSM leader, who told him that he had obtained incriminating evidence against him from foreign intelligence services and urged the premier to resign and allow the formation of a caretaker administration. As Gruevski was preparing to prosecute Zaev on charges of attempting a coup, the opposition chief released recordings, dubbed 'bombs', which allegedly revealed that the government had been secretly wiretapping the conversations of over 20000 people as well as revealing the supposed involvement of public and government officials in corruption, electoral fraud, abuse of power and money laundering. This fostered mass anti-government demonstrations in May and June 2015 (Stavrevska, 2015a; Vanhoutte, 2016; Deliso, 2017; Gjorgjioska \& Vangeli, 2017).

The wiretapping scandal incentivised the EU and the US to interfere in Macedonian politics yet again. In June, as an outcome of mediation by the European Commission and Parliament with US backing, the governing and opposition parties signed the Pržino Agreement, which stipulated that the SDSM MPs would return to parliament and be allocated certain ministries and that a new government led by a VMRO-DPMNE appointee would take charge in January 2016 in order to prepare for free and fair elections in April. It was clear from the onset that in this process the EU took the lead, especially because no previous crisis, except for the 2001 insurgency, had been treated with such high political investment by the Commission. Even US participation was more or less due to the initiative of EU mediator Peter Vanhoutte. Moreover, potential EU accession was used as an impetus in the negotiations (Bogdanovski, 2015; Markovikj \& Damjanovski, 2018). 


\section{Seceururity}

More importantly, the implementation of the Pržino Agreement was set as a condition to begin accession talks (Kmezić, 2019).

The EU's intervention in Macedonia through the Pržino Agreement can also be explained by a realist assessment of the European geopolitical context in 2015. As mentioned previously, the Union's primary goal in the Balkans is to guarantee prosperity and stability. Apart from this, the EU is using the Balkans to test its capabilities in order to establish a sphere of influence. In addition, the EU's priority is energy security and as such the Union attempts to reduce its energy dependency to a small number of suppliers, like Russia or Middle Eastern oil-producing countries. Within this backdrop, the EU aims to absorb the Balkans into the European regional market for gas and petroleum-derived products. Energy geopolitics forces EU countries and policy planners to secure future energy needs in and through the Balkans, so any instability in this region can seriously affect the passage of oil and gas to the West. Moreover, the Balkans represent a human security threat to the EU because of migrant smugglers, potential terrorists, criminals and drugs coming from this area, particularly from Kosovo (Bobić, 2015).

Despite efforts to create a sphere of influence, after the eurozone crisis began in 2008 and Croatia became the newest member state in 2013 the EU entered a phase of 'enlargement fatigue' as it had to confront internal financial and identity crises, the controversy over the candidacy of Turkey and the lack of consensus among member states about common aims and priorities for the Balkans. The inability to offer a plausible enlargement perspective to candidate countries enabled the rise of China, Russia, the Gulf states and Turkey as contenders for influence in the region (Fererro-Turrión, 2015; Della Sala \& Belloni, 2019). Matters worsened with the 2014 Ukrainian crisis which damaged relations between the West and the Russian Federation. This happened largely due to EU and NATO expansion and Western democracy promotion efforts in countries like Georgia and perhaps even Russia itself (Mearsheimer, 2019).

The above-mentioned issues did not hinder some EU member states from maintaining their own interests vis-à-vis enlargement in the Balkans. From a realist view, the stronger countries like Germany and France play an important role in developing the Union's foreign policy which is based primarily on security concerns. So many of the initiatives and missions carried out under a European label can be described as mini-lateral or unilateral policies tolerated by other member states (Bendiek, 2012). Germany is one of the main supporters of EU enlargement principally because, in realist terms, this policy represents "a kind of German self-help strategy to respond to new security challenges and threats in a radically changed post-Cold War geo-political environment in Europe since the 1990s" (Reichwein, 2019:94). After 1991, the newly unified Germany dreaded a security vacuum between its eastern border and Russia and therefore stability and security concerns influenced the country's enlargement policy from the 1990s onwards, meaning that it still plays a major role in providing and promoting regional stability. The Union's enlargement, which was compatible with German security and economic interests, allowed Berlin to have a new sphere of influence in Eastern Europe (Ibid, 95-96). In fact, Germany has been regarded as the financial winner of the enlargement process, since its economic influence stretches beyond the EU's core and periphery. German capital and banks have hegemony over the Western Balkans and 
thus Germany is Macedonia's most prominent economic partner (Vankovska, 2020). The belief of a growing Russian threat in the region motivated Germany, with support from Austria, Britain, France, Italy, Slovenia and Croatia, to renew the EU's engagement in this particular area, since it is increasingly considered by Brussels to be strategic (Della Sala \& Belloni, 2019). In this regard Macedonia is also of strategic interest because its geopolitical and geophysical position allows it to function as a pivotal link between the Greek ports and the Central Balkan states as well as Germany and Hungary. Additionally, its territory is not just the main passage for the north-south regional trade, but also an accessible corridor for migrants from outside Europe (Mitrevska \& Ruzhin, 2018).

Macedonia's foreign policy in the aftermath of the 2001 conflict focused on the same strategic priorities, i.e. EU and NATO accession and resolution of disputes with its neighbours (Koneska, 2014). As stated above, Macedonia was effectively bandwagoning towards the EU, something "most likely to occur when a weak state believes that aligning with the dominant power will eliminate or deflect the threat and thereby advance its main interests" (Walt, 2009:109-110). Hence, the country embraced Western foreign policy in the hope that it would avoid the problems faced by its former Yugoslav counterparts and thus gain peace and prosperity. However, this did not avert the 2001 insurgency and the country remains one of the poorest in Europe (Malagurski, 2020).

Due to Western-dominated unipolarity, the Macedonian state has accepted the idea that there is no alternative to EU and NATO integration since these processes are perceived as necessary for domestic stability. Moreover, the intensification of external state-building efforts since the hostilities in 2001 has fostered dependency on the EU and US in internal and foreign affairs. Nonetheless there were some alterations after Gruevski took power in 2006. He was committed to Euro-Atlantic institutions, but when the EU experienced an economic downturn, Macedonia turned towards the more dynamic Asian economies in order to augment foreign investments and other economic enterprises that would stimulate growth. It even established links with the Russian Federation in the energy sector via an inclusion in the South Stream gas pipeline as a means of obtaining natural gas (Koneska, 2014; Petsinis, 2015; Vankovska, 2017). When the Ukrainian crisis erupted in 2014, Macedonia was in a difficult position since it maintained a pro-EU orientation but wished to have good relations with Russia, due to the fact that the country was supposed to participate in the South Stream project. Nevertheless, the European Commission wanted it discontinued because it contradicted EU legislation (Vankovska, 2014). Macedonia's reluctance to apply sanctions fostered accusations by Macedonian pro-government circles and the Russian authorities that the US and EU were trying to orchestrate a 'colour revolution' involving protests organised by Western-backed NGOs so that Gruevski's government could be destabilised and cooperation with Moscow could be hindered (Bogdanovski, 2015; Petsinis, 2015; Sputnik, 2015). In this light, the forced resignation of Gruevski was considered by his supporters as the removal of a legitimately elected leader (Stavreska, 2015b) and therefore it can be contended that the $\mathrm{EU}$, in collusion with the US, was acting according to offensive realism which declares that great powers could attempt to oust a democratic regime if it appears hostile to their material security and economic interests (Miller, 2010). 
The implementation of the Pržino Agreement went ahead in October 2015 when a transitional administration comprising both VMRO-DPMNE and SDSM ministers was installed and in January 2016 Gruevski was replaced by fellow party member Emil Dimitriev. Everything appeared to be going smoothly until April when the Macedonian president Gjorge Ivanov issued a pardon to those implicated in the wiretapping scandal, sparking a new wave of street protests. Confronted by domestic and international pressure, Ivanov withdrew his pardon. Leaders from the EU and the US intervened again in the country's affairs, emphasising the apparent democratic backsliding. Protests continued until July when the Union mediated meetings between EU officials, government and opposition politicians, resulting in a new deal which set new elections for December 2016 (Mano, 2016; Marolov, 2016; Reef, 2017). In its 2016 progress report on Macedonia, "the European Commission used the term 'state capture' to describe how the institutions in an accession country were being undermined and could not work for the common good" (Bieber, 2020:110). So for the first time, the EU openly drew attention to regression in democracy and Commissioner Johannes Hahn forewarned Macedonia that if reforms were not enacted, it would become the first state for whom the Union relinquished its candidacy (Gafuri \& Muftuler-Bac, 2020). It has been postulated that this was a stark change in the EU's position which had entailed the prioritisation of democracy over stability (Ibid). However matters were more complex than they seemed.

The 2016 progress report only revealed what was clear to many people before. Gruevski simply refined the system of clientelism and state capture of his predecessors and by the time he left office his party and its Albanian coalition partner DUI had consolidated patronage networks at both local and national levels (Grabbe, 2015; Deliso, 2017). While in 2011 Macedonia was considered a 'semi-consolidated democracy' (Richter, 2012), in 2015 it was described as a hybrid regime (Kolozova \& Šišovski, 2015). The EU shares a significant degree of responsibility for this phenomenon since it kept Macedonia at a distance for much of Gruevski's tenure, despite nine positive recommendations by the European Parliament and Commission to initiate accession talks. This was initially due to the name dispute with Greece, but then internal crises within the Union stalled the enlargement process, diminishing hopes of Macedonia joining the EU and allowing VMRO-DPMNE and DUI to capture the state. Although the EU's Copenhagen Criteria was supposed to consolidate democracy in candidate countries, the lack of an accession prospect diminished the need for substantial reforms, thus contributing to the rise of authoritarian tendencies. However, some European governments tolerated state capture as long as Macedonia kept migrants out and accepted foreign investors (Gjoni \& Less, 2016; Günay \& Dzihic, 2016; Vankovska, 2019b). In fact the country turned out to be the EU's major partner in efforts to block the influx of migrants in 2015 crossing through the Balkans (Szpala, 2016). During VMRO-DPMNE's 2016 election campaign, the former Austrian foreign minister Sebastian Kurz appeared at a rally praising the Macedonian government for closing the Western Balkan refugee route earlier that year at Austria's initiative. Receiving external support if their claim of maintaining stability is dependable and helps geostrategic interests is a characteristic of 'stabilitocracies', i.e. regimes that mix semi-authoritarian features with deficient democratic governance, yet enjoy foreign backing by providing some apparent stability. Obviously, this kind of transaction has been a 


\section{Seecururity}

feature of Western assistance to non-democratic states for decades, especially during the Cold War (Bieber, 2018). The commitment of authoritarian establishments in the Western Balkans to EU integration has made them harder to challenge since the EU's focus on stability has meant that the illiberal practices of such elites have been disregarded by European governments who only interfered when mass protests and political crises reached a critical peak, as in the case of Macedonia (Keil, 2018).

A typical outcome of the stabilitocracy "game" is political chaos and radicalisation as exemplified by the aftermath of the 2016 Macedonian parliamentary elections (Pavlović, 2017) which resulted in another victory for VMRO-DPMNE, but without enough seats to form a majority. Gruevski could have returned to power with his long-time ethnic Albanian coalition partner DUI, but the latter decided to support Zaev. Shortly after the elections, the Macedonian Albanian parties signed the so-called 'Tirana Platform' which made their entry into a new government conditional on the acceptance of maximalist demands, including making Albanian the second official language in Macedonia (although Albanians live mainly in the country's western areas). Zaev went along with this arrangement. However, Ivanov prevented him from forming a government. The US, NATO and EU attempted to persuade the President to authorise the creation of a SDSM-led administration, while Russia backed VMRO-DPMNE's denunciations of external intervention. Western interference sparked three months of patriotic demonstrations around the country that culminated on 27th April 2017 when SDSM and DUI irregularly elected a DUI member and former NLA fighter as parliamentary speaker. Consequently, several protestors entered parliament and some MPs, including Zaev, were injured. Macedonia was therefore on the verge of civil war (Daskalovski \& Trajkovski, 2017; Deliso, 2017; Rettman, 2017).

What happened in Macedonia during 2015-17 can be described as an example of transnational penetration, which is defined by Stephen M. Walt as "the manipulation of one state's domestic political system by another" (1987:46). He asserted that penetration is more effective when it is aimed at open democratic societies, rather than closed authoritarian states, since they are more susceptible to foreign propaganda or lobbyists representing the interests of other countries. Moreover, the success of penetration is linked to the ends. If a state wishes to ensure alignment by trying to subvert a regime via antagonistic propaganda or support for opposition groups for example, then the target state will retaliate negatively against whichever country is managing the campaign (Ibid, 47-48). Macedonia was perceived by the US and the EU to be a reliable ally, but when Gruevski chose to pursue policies that they did not condone, such as refusing to place sanctions on Russia over the Ukrainian crisis, both Washington and Brussels expressed their increasing disaffection, while their diplomats and media gave overt support to Zaev. It was rumoured that German, Italian and British secret services had been involved in the wiretapping affair. Furthermore, certain media reports claimed that Italy was indirectly implicated in bringing together Zaev and the drafters of the Tirana Platform and that the former Italian prime minister Matteo Renzi, then-US President Barack Obama and Edi Rama jointly agreed to back SDSM's bid for power. Gruevski reacted to this penetration by depicting foreign embassies and the American-Hungarian philanthropist George Soros as enemies of Macedonia. These suppositions fuelled 
the nationalist protests in early 2017 against a potential Zaev administration (Deliso, 2017; Reef, 2017; Vankovska, 2020). In the end, the EU and US penetration of Macedonia succeeded as Ivanov eventually succumbed to growing external pressure and authorised Zaev to form a government in May 2017 (Chryssogelos \& Stavrevska, 2019).

After obtaining his mandate Zaev turned towards settling foreign policy disputes with Greece and Bulgaria, rather than satisfying popular expectations. He soon began negotiations with his Greek counterpart Alexis Tsipras to resolve the name dispute between Macedonia and Greece with the encouragement of the European Commission. This controversy was the remaining Macedonia-related issue to be resolved since it obstructed the process of international state-building (Ioannides, 2018; Vankovska, 2019a). In June 2018 Zaev and Tsipras signed the Prespa Agreement which was supposed to end the name dispute. It entailed the change of Macedonia's constitutional name to the 'Republic of North Macedonia' for both domestic and international use (erga omnes) in exchange for Greece lifting its veto against its neighbour's EU and NATO accession. Behind this apparent gesture of goodwill it was clear that both the EU and the US were involved in the discussions that led to the Agreement's signing. The Western powers had an interest in ending the name dispute so as to bring Macedonia within the Euro-Atlantic sphere and undermine Russian influence in the Balkans. The fall of the Gruevski government in 2016 was therefore a chance to guarantee that Macedonia would remain aligned with the West (Unkovski-Korica, 2018; Nimetz, 2020; Vankovska, 2020). Few global actors were more enthusiastic for the Prespa Agreement than the EU. Its foreign affairs commissioner Mogherini and enlargement commissioner Johannes Hahn were present at the signing of the document and in the following months EU officials championed the ratification process. For the Union, the deal was an opportunity to revive the stalled enlargement process as well as a strategic triumph against other external actors, like Russia, China and Turkey (Chryssogelos \& Stavrevska, 2019).

The signing of the Prespa accord was followed by a "long list of violations of the rule of law and democratic principles in order to push forward the name change and the geopolitical agenda" (Vankovska, 2019a:116). After signing the deal Zaev held a referendum in Macedonia on 30th September 2018 asking the Macedonian people whether they were in favour of joining the EU, NATO and the accord with Greece, all three in one question. During the referendum campaign Zaev claimed that his country needed a "whipper" from the EU and NATO to tackle its difficulties, which is the epitome of a viewpoint shared by some Macedonian politicians and voters who believe that membership of Western structures would ensure Macedonia's development and survival (Gagovska, 2018). In the current multipolar world, joining an alliance is seen as the best option for small states, particularly Western Balkan ones, to protect themselves from the anarchy that characterises global affairs, to advance their foreign policy interests and to diminish "the uncertainty that exists in contemporary international relations" (Begović, 2018:48).

The referendum resulted in a defeat for the SDSM-led administration because although there was 91 percent approval for the name deal and EU and NATO membership, turnout was 36.91 percent which was below the 50 percent minimum threshold needed to validate the result. Despite this, Zaev proclaimed the referendum to be a success. Foreign officials like Hahn persuaded the 
prime minister to ignore the result, arguing that the Prespa accord had received significant backing (Republika English, 2018; Unkovski-Korica, 2018). Hahn spurred Zaev to use a "combination of the Balkan and rational approach" to attain the two-thirds parliamentary majority required to alter the Macedonian constitution and rubber-stamp the name agreement (Vankovska, 2019b:73). The prime minister did so by bribing, blackmailing or intimidating eight VMRO-DPMNE MPs to vote with the government on 19th October 2018. The ratification process in Greece in January 2019 also raised eyebrows because Tsipras co-opted a number of parliamentarians with the promise of government jobs or inclusion in his electoral lists. Such a move contradicted parliamentary and constitutional norms and aggravated the mistrust towards the political system among ordinary Greeks. From a geopolitical standpoint, the forceful imposition of the name accord has shown that the document does not guarantee stability, friendship or peace in the Balkans, but is aimed at keeping the region in the Euro-Atlantic sphere of influence and, in the case of Macedonia, Western foreign-policymakers have revitalised the Soviet Brezhnev Doctrine of restricted sovereignty for client states (Chryssogelos, 2019; Vankovska, 2019a).

In the aftermath of the Prespa Agreement's ratification, Zaev and DUI strengthened their hold on power after their consensual candidate Stevo Pendarovski won the 2019 presidential election, although this was marked by irregularities such as bribing and blackmailing voters (Pankovski \& Mladenovska, 2019). At this point Zaev felt that he was untouchable and above the law but his government's reputation was soon tarnished by a racketeering scandal. Evidence provided by audio and visual leaks, also dubbed 'bombs', demonstrated the SDSM prime minister's participation in an extortion scheme. This is arguably the key reason why the French president Emmanuel Macron blocked the start of accession talks with Macedonia in late 2019, leading to Zaev's replacement in January 2020 by a Pržino-style caretaker administration. Macedonians had realised that they had simply swapped one regime for another, with a new state capture carried out by SDSM and DUI and with the country's corruption and democracy indexes worsening from 2017 onwards, Macedonia mainained the status of a hybrid regime (Sela, 2019; Vankovska, 2019b; Pankovski et al, 2020; Waters, 2020). In July 2020 early parliamentary elections were held resulting in a marginal victory for the SDSM-led electoral coalition, which later formed a government with DUI that has a razor-thin majority of 62 MPs (Stamouli, 2020). The democratic credentials of SDSM and DUI were not encouraging in 2017 (Daskalovski, 2017) and they have certainly not improved since then. This substantiates the point made by Florian Bieber that stabilitocracies can "either swing towards more democratic rule or greater authoritarianism and collapse" (2018:184).

Macedonia's path towards full European integration remains uncertain. Although in March 2020 the European Council approved the start of accession talks with the country, the Union still cannot offer a realistic membership perspective (Gafuri \& Muftuler-Bac, 2020). From the EU's perspective, enlargement is not a priority at present. Macron and other EU leaders prefer to concentrate on resolving internal issues, such as reforming the eurozone. This explains why the French president vetoed the beginning of membership negotiations in October 2019 and only gave its consent after the European Commission conceded the reopening of some closed agreements with Macedonia. Overall, there is a chance that the country will be stuck in talks for much of the 
upcoming decade and its compliance with the demands from Brussels might diminish over time (Bechev, 2020). Moreover, the lack of cohesion between EU member states on enlargement and foreign policy continues to be a problem as exemplified by the fact that currently Macedonia is engaged in discussions with Bulgaria to resolve disputes over history and language (Chryssogelos \& Stavrevska, 2019). In December 2020, Sofia vetoed the start of accession talks with Skopje, demonstrating the asymmetry of power between EU and candidate countries and how Brussels does not possess the wish or the instruments to halt such behaviour. The Union's weak response also shows "the hypocrisy of a Union which promotes laudable values, e.g. peace, democracy and human rights, but often fails to defend them or sacrifices them for pragmatic motives, just as any great power would do" (Waters, 2021).

The ongoing anti-coronavirus vaccination rollout is further proof of both Macedonia's bandwagoning and the EU's incapacity to fulfill its promises. The country initially relied on the EU for vaccine procurements, but seeing that nothing was coming from the Union until late April 2021 Macedonia turned to Serbia, Russia and China for help. In the meantime, it also became the state with the fourth worst COVID-19 death rate worldwide. The already damaged perception of the EU in the Western Balkans is definitely not recovering (Republika English, 2021a; Republika English, 2021b; Republika English, 2021c; Stamouli, 2021; Statista, 2021).

\section{Conclusion}

The aim of this paper was to assess the impact of EU state-building policies, i.e. conditionality and enlargement procedures, on the democratisation process in Macedonia from the country's independence in 1991 to the present day. Using realism as a theoretical approach to analyse events and trends during the three phases of EU state-building in Macedonia, this study has tried to demonstrate that the Union's behaviour towards the landlocked Balkan republic has produced an asymmetrical relationship based on fulfillment of demands and conditions without receiving any credible accession prospect. It has also resulted in a gradual backsliding of the country's democratic governance. The reality is that the geopolitical and security interests of EU member states are the main factors that shape the Union's policies towards Macedonia, and the Balkan region in general. Such considerations have become prominent in recent years due to growing competition from Russia, China and Turkey. Additionally, Macedonia's attitude towards the EU can be described as an example of bandwagoning with the neighbouring stronger powers in order to gain rewards or a guarantee of stability. The evidence shows that Macedonia has not received many benefits from its alignment with the EU in terms of building a functioning liberal democracy.

From the country's declaration of independence until the new millenium, its political establishment laid the groundwork for state capture and clientelism that have persisted ever since. The relationship with the EU was limited, but the Union was still able to provide assistance during the early democratisation process. After the 2001 insurgency both the EU and the US imposed the Ohrid Framework Agreement, a power-sharing model that did little to unite the Macedonian and Albanian communities and only managed to transform the country into a semi-protectorate. This was followed by a Western-backed transnational penetration in 2015-17 which installed a more 


\section{Seceururity}

servile government. Currently, Macedonia is far from being a consolidated democracy as shown by the questionable ratification of the Prespa Agreement for instance. Instead it is a hybrid regime whose controversial practices are tolerated by the EU as long as they satisfy the interests and goals of the member states. The lack of an accession prospect due to internal difficulties or opposition from certain countries displays how enlargement fatigue affects EU policy-making. It also corroborates the realist argument that European regional integration has not stopped individual states from pursuing their own agenda at others' expense, thus making the Union unable to have a coherent foreign policy or state-building approach. Such incapability was further demonstrated by the EU's failure to give vaccines to Macedonia during the coronavirus pandemic.

The Macedonian story teaches us that the supposedly benign intentions of foreign powers should always be questioned and that in most cases it is better to build a functioning political system without external guidance. Despite the encouraging rhetoric, the EU in reality does not show any intention of pursuing a swift enlargement process with Macedonia or any other candidate country. As things stand, it could be not years, but decades before the Union's attitude changes. Consequently, it might be appropriate for Macedonia to reconsider its relationship with the EU by enhancing its own political, judicial and economic system and looking at alternatives to full membership.

\section{Bibliography}

1. Babayan, Nelli \& Risse, Thomas (2017) Transatlantic democracy promotion: cooperation in crisis. International Politics, vol. 54, pp. 221-237.

2. Bechev, Dimitar (2020) North Macedonia's Success Story May be About to End. [Online] Available from: https://foreignpolicy.com/2020/07/24/north-macedonia-success-story-nato-eu-populism/ [Accessed 8th May 2021].

3. Begović, Monika (2018) South-Eastern Europe security in a multipolar world: a need for stronger integration. Contemporary Macedonian Defence, vol. 18, no. 34, pp. 37-48.

4. Bendiek, Annegret (2012) European Realism in the EU's Common Foreign and Security Policy. In: Cardwell, Paul James (ed.) EU External Relations Law and Policy in the Post-Lisbon Era. T.M.C. Asser Press, pp. 35-57.

5. Berg, Eiki \& van Meurs, Wim (2002) Borders and Orders in Europe: Limits of Nation- and State-Building in Estonia, Macedonia and Moldova. The Journal of Communist Studies and Transition Politics, vol. 18, no. 4, pp. 51-74.

6. Bieber, Florian (2011a) Building Impossible States? State-Building Strategies and EU Membership in the Western Balkans. Europe-Asia Studies, vol. 63, no. 10, pp. 1783-1802.

7. Bieber, Florian (2011b) Introduction: Assessing the Ohrid Framework Agreement. In: Risteska, Marija \& Daskalovski, Zhidas (eds.) One Decade after the Ohrid Framework Agreement: Lessons (to be) Learned from the Macedonian Experience. Skopje, Friedrich Ebert Stiftung, Center for Research and Policy Making, pp. 12-27.

8. Bieber, Florian (2018) The Rise (and Fall) of Balkan Stabilitocracies. Horizons: Journal of International Relations and Sustainable Development, no. 10, pp. 176-185. 
9. Bieber, Florian (2020) The Rise of Authoritarianism in the Western Balkans. Palgrave Macmillan.

10. Bliesemann de Guevara, Berit (2010) Introduction: The Limits of Statebuilding and the Analysis of State-Formation. Journal of Intervention and Statebuilding, vol. 4, no. 2, pp. $111-128$.

11. Bobić, Marinko (2015) Congruous or Conflicting? Great Power Configurations in the Balkans. In: Klieman, Aharon (ed.) Great Powers and Geopolitics: International Affairs in a Rebalancing World. Springer International Publishing Switzerland, pp. 87-111.

12. Bogdanovski, Andreja (2015) Macedonia - Back in the Global Spotlight. Policy Brief 20/2015. 0slo: Norwegian Institute for International Affairs (NUPI). Available at: https://nupi.brage. unit.no/nupi-xmlui/handle/11250/302497 (Accessed 8th May 2021).

13. Carpenter, Ted Galen (2002) Kosovo and Macedonia: The West Enhances the Threat. Mediterranean Quarterly, vol. 13, no. 1, pp. 21-37.

14. Cavoski, Aleksandra (2015) Idealism or Realism in the Process of EU Enlargement: The Case of Serbia. East European Quarterly, vol. 43, no. 4, pp. 265-292.

15. Chivvis, Christopher S. (2008) The Making of Macedonia. Survival, vol. 50, no. 2, pp. 141-162.

16. Chryssogelos, Angelos (2019) Macedonia's Name Change Deal Is a Triumph for the E.U., But Worrying for Democracy. [Online] Available from: https://time.com/5508640/prespes-macedonia-greece-eu-democracy/ [Accessed 8th May 2021].

17. Chryssogelos, Angelos \& Stavrevska, Elena B. (2019) The Prespa Agreement Between Greece and North Macedonia and the Discordancies of EU Foreign Policy. European Foreign Affairs Review, vol. 24, no. 4, pp. 427-446.

18. Crowther, William (2017) Ethnic Condominium and Illiberalism in Macedonia. East European Politics and Societies: and Cultures, vol. 31, no. 4, pp. 739-761.

19. Daskalovski, Zhidas (1999) Democratisation in Macedonia and Slovenia. South-East Europe Review for Labour and Social Affairs, vol. 2, no. 3, pp. 17-44.

20. Daskalovski, Zhidas (2004) Democratic consolidation and the 'stateness' problem: The case of Macedonia. The Global Review of Ethnopolitics, vol. 3, no. 2, pp. 52-66.

21. Daskalovski, Zhidas (2017) state capture: how to save the Macedonian democratic consolidation and EU enlargement. Perspectives Southeast Europe, no. 3, pp. 20-25.

22. Daskalovski, Zhidas \& Trajkovski, Kristijan (2017) Macedonian Obama or the platform from Tirana: How to get the votes of the "Others" and what to do with them? Skopje, Center for Research and Policy Making.

23. Deliso, Chris (2017) Macedonia's Crisis Isn't Going Away. [Online] Available from: https:// www.the-american-interest.com/2017/03/05/macedonias-crisis-isnt-going-away/ [Accessed 8th May 2021].

24. Della Sala, Vincent \& Belloni, Roberto (2019) Realism in the EU: Can a Trans-national Actor Be Strategic? In: Belloni, Roberto, Della Sala, Vincent \& Viotti, Paul (eds.) Fear and Uncertainty in Europe: The Return to Realism? Palgrave Macmillan, pp. 241-263.

25. Dimitrov, Plamen (2011) Ohrid Framework Agreement and its implication for the Balkan geopolitical status quo. In: Risteska, Marija \& Daskalovski, Zhidas (eds.) One Decade after the Ohrid Framework Agreement: Lessons (to be) Learned from the Macedonian Experience. Skopje, Friedrich Ebert Stiftung, Center for Research and Policy Making, pp. 246-263. 
26. Dini, Lamberto (1997) 'Intervento introduttivo', II ruolo dell'Italia nella cooperazione politica ed economica con l'Europa danubiano-balcanica. Rome, 13th June. Roma: Servizio Stampa e informazione del Ministero degli Affari esteri, pp. 13-22.

27. Dobbins, James, Jones, Seth G., Crane, Keith, Chivvis, Christopher S., Radin, Andrew, Larrabee, F. Stephen, Bensahel, Nora, Stearns, Brooke K. \& Goldsmith, Benjamin W. (2008) Europe's Role in Nation-Building: From the Balkans to the Congo. RAND Corporation.

28. Fassino, Piero (1997) 'Intervento introduttivo', II ruolo dell'Italia nella cooperazione politica ed economica con l'Europa danubiano-balcanica. Rome, 13th June. Roma: Servizio Stampa e informazione del Ministero degli Affari esteri, pp. 71-80.

29. Fererro-Turrión, Ruth (2015) The EU approach to the Western Balkans: a security or political issue? Europolity, vol. 9, no. 2, pp. 11-27.

30. Gafuri, Adea \& Muftuler-Bac, Meltem (2020) Caught between stability and democracy in the Western Balkans: a comparative analysis of paths of accession to the European Union. East European Politics, https://doi.org/10.1080/21599165.2020.1781094.

31. Gjoni, Roland \& Less, Timothy (2016) Macedonia's elections: how the EU continues to fail the Western Balkans. [Online] Available from: https://www.opendemocracy.net/en/caneurope-make-it/macedonia-s-elections-how-eus-continues-to-fail-western/ [Accessed 8th May 2021].

32. Gjorgjioska, Adela \& Vangeli, Anastas (2017) Macedonia in Crisis. [Online] Available from: https://jacobinmag.com/2017/02/macedonia-corruption-ethnic-politics-levica-protests [Accessed 8th May 2021].

33. Cjuzelov, Borjan \& Hadjievska, Milka Ivanovska (2020) Institutional and symbolic aspects of illiberal politics: the case of North Macedonia (2006-2017). Southeast European and Black Sea Studies, vol. 20, no. 1, pp. 41-60.

34. Gromes, Thorsten (2009) Between Impositions and Promises: Democracy in Macedonia. PRIF-Reports No. 91. Frankfurt am Main: Peace Research Institute Frankfurt (PRIF).

35. Günay, Cengiz \& Dzihic, Vedran (2016) Decoding the authoritarian code: exercising 'legitimate' power politics through the ruling parties in Turkey, Macedonia and Serbia. Southeast European and Black Sea Studies, vol. 16, no. 4, pp. 529-549.

36. Hislope, Robert (2003) Between a bad peace and a good war: insights and lessons from the almost-war in Macedonia. Ethnic and Racial Studies, vol. 26, no. 1, pp. 129-151.

37. Holliday, Graham (2005) From Ethnic Privileging to Power-Sharing: Ethnic Dominance and Democracy in Macedonia. In: Smooha, Sammy \& Järve, Priit (eds.) The Fate of Ethnic Democracy in Post-Communist Europe. Budapest, Local Government and Public Service Reform Initiative, Open Society Institute, pp. 139-165.

38. Howorth, Jolyon (2014) Security and Defence Policy in the European Union. Second Edition. Basingstoke, Palgrave Macmillan.

39. Hurrell, Andrew (1995) Explaining the Resurgence of Regionalism in World Politics. Review of International Studies, vol. 21, no. 4, pp. 331-358.

40. Hyde-Price, Adrian (2008) A 'Tragic Actor'? A Realist Perspective on 'Ethical Power Europe'. International Affairs (Royal Institute of International Affairs 1944-), vol. 84, no. 1, pp. 29-44.

41. Ilievski, Zoran \& Taleski, Dane (2009) Was the EU's Role in Conflict Management in Macedonia a Success? Ethnopolitics, vol. 8, no. 3-4, pp. 355-367. 
42. Ioannides, Isabelle (2018) Peace and Security 2018: An evaluation of EU peacebuilding in the Western Balkans. Brussels, European Parliamentary Research Service.

43. Keil, Soeren (2018) The Business of State Capture and the Rise of Authoritarianism in Kosovo, Macedonia, Montenegro and Serbia. Southeastern Europe, vol. 42, no. 1, pp. 59-82.

44. Kmezić, Marko (2019) EU Rule of Law Conditionality: Democracy or 'Stabilitocracy' Promotion in the Western Balkans? In: Džankić, Jelena, Keil, Soeren \& Kmezić, Marko (eds.) The Europeanisation of the Western Balkans: A Failure of EU Conditionality? Palgrave Macmillan, pp. 87-110.

45. Kolozova, Katerina \& Šišovski, Jordan (2015) Macedonia: the authoritarian challenge to Europe. [Online] Available from: https://www.opendemocracy.net/en/can-europe-makeit/macedonia-authoritarian-challenge-to-europe/ [Accessed 8th May 2021].

46. Koneska, Cvete (2014) Policy Consensus During Institutional Change: Macedonian Foreign Policy Since Independence. In: Keil, Soeren \& Stahl, Bernhard (eds.) The Foreign Policies of Post-Yugoslav States: From Yugoslavia to Europe. Palgrave Macmillan, pp. 97-121.

47. Levitsky, Steven \& Way, Lucan A. (2010) Competitive Authoritarianism: Hybrid Regimes After the Cold War. Cambridge, New York, Cambridge University Press.

48. Lund, Michael S. (2000) Preventive Diplomacy for Macedonia, 1992-1999: From Containment to Nation Building. In: Jentleson, Bruce W. (ed.) Opportunities Missed, Opportunities Seized: Preventive Diplomacy in the Post-Cold War World. Lanham, Oxford, Rowman \& Littlefield Publishers, Inc, pp. 173-210.

49. Malagurski, Boris (2020) Serbia-Kosovo 'normalization of relations' plan: Will Belgrade give in to Western demands \& shift toward 'mutual recognition'?[0nline] Available from: https:// www.rt.com/op-ed/503993-serbia-kosovo-us-recognition/ [Accessed 8th May 2021].

50. Mano, Viktorija (2016) Macedonian election preview: Will the vote provide an answer to the country's political crisis? [Online] Available from: https://blogs.lse.ac.uk/europpblog/2016/12/08/macedonia-election-preview-2016/ [Accessed 8th May 2021].

51. Markovikj, Nenand \& Damjanovski, Ivan (2018) The EU's Democracy Promotion Meets Informal Politics: The Case of Leaders' Meetings in the Republic of Macedonia. REGION: Regional Studies of Russia, Eastern Europe, and Central Asia, vol. 7, no. 2, pp. 71-96.

52. Marolov, Dejan (2016) A perfect storm: Macedonia's political chaos and the refugee crisis. [Online] Available from: https://blogs.lse.ac.uk/europpblog/2016/01/28/a-perfect-storm-macedonias-political-chaos-and-the-refugee-crisis/ [Accessed 8th May 2021].

53. Mearsheimer, John J. (2010) Why is Europe Peaceful Today? European Political Science, vol. 9, no. 3, pp. 387-397.

54. Mearsheimer, John J. (2019) Bound to Fail: The Rise and Fall of the Liberal International Order. International Security, vol. 43, no. 4, pp. 7-50.

55. Mihaila, Roxana (2012) Europeanisation Faces Balkanisation: Political Conditionality and Democratisation-Croatia and Macedonia in Comparative Perspective. European Perspectives: Journal on European Perspectives of the Western Balkans, vol. 4, no. 1, pp. 13-34.

56. Miller, Benjamin (2010) Democracy Promotion: Offensive Liberalism versus the Rest (of IR Theory). Millenium: Journal of International Studies, vol. 38, no. 3, pp. 561-591.

57. Mitrevska, Marina \& Ruzhin, Nano (2018) Geopolitics of the Western Balkans $\otimes$ an area of geopolitical competition of the great powers. Contemporary Macedonian Defence, vol. 18 , no. 34, pp. 21-36. 
58. Morlino, Leonardo (2009) Are there hybrid regimes? Or are they just an optical illusion? European Political Science Review, vol. 1, no. 2, pp. 273-296.

59. Nimetz, Matthew (2020) The Macedonian "Name" Dispute: The Macedonian QuestionResolved? Nationalities Papers: The Journal of Nationalism and Ethnicity, vol. 48, no. 2, pp. 205-214.

60. Pankovski, Marko \& Mladenovska, Simona (2019) The Republic of North Macedonia's 2019 presidential election handbook. Second updated edition. Konrad Adenauer Foundation, Institute for Democracy "Societas Civilis"-Skopje.

61. Pankovski, Marko, Joveska-Cjorgjevikj, Aleksandra, Janeska, Sara, Ilievska, Martina \& Mladenovska, Simona (2020) The Republic of North Macedonia's 2020 Parliamentary Elections Handbook. Second updated edition. Konrad Adenauer Foundation, Institute for Democracy "Societas Civilis" Skopje.

62. Pavlović, Srđa (2017) West is best: How 'stabilitocracy' undermines democracy building in the Balkans. [Online] Available from: https://blogs.lse.ac.uk/europpblog/2017/05/05/ west-is-best-how-stabilitocracy-undermines-democracy-building-in-the-balkans/ [Accessed 8th May 2021].

63. Petsinis, Vassilis (2015) From pro-American to pro-Russian? Nikola Gruevski as a political chameleon. [0nline] Available from: https://www.opendemocracy.net/en/can-europemake-it/from-proamerican-to-prorussian-nikola-gruevski-as-political-cha/ [Accessed 7th May 2021].

64. Pond, Elizabeth (2006) Endgame in the Balkans: Regime Change, European Style. Brookings Institution Press.

65. Reef, Paul (2017) Macedonia's Colourful Revolution and the Elections of 2016. A Chance for Democracy, or All for Nothing? Südosteuropa, vol. 65, no. 1, pp. 170-182.

66. Republika English (2018) SEC preliminary results: 666,743 voted, $91.46 \%$ Yes, 5.65\% No. [Online] Available from: https://web.archive.org/web/20181001182815/http://english. republika.mk/p205391/ [Accessed 9th May 2021].

67. Republika English (2021a) Vucic explained how he got the vaccines: I'm more experienced than my friend Zaev, who relied entirely on the EU and didn't get vaccines. [Online] Available from: https://english.republika.mk/news/balkans/vucic-explained-how-he-got-the-vaccinesim-more-experienced-than-my-friend-zaev-who-relied-entirely-on-the-eu-and-didntget-vaccines/ [Accessed 9th May 2021].

68. Republika English (2021b) Siljanovska to Zaev: There is no room for East-West games when you need to obtain vaccines. [Online] Available from: https://english.republika.mk/news/ siljanovska-to-zaev-there-is-no-room-for-east-west-games-when-you-need-to-obtainvaccines/ [Accessed 9th May 2021].

69. Republika English (2021c) EU and Austria announce a shipment of Pfizer vaccines for the Balkan countries. [Online] Available from: https://english.republika.mk/news/macedonia/eu-and-austria-announce-a-shipment-of-pfizer-vaccines-for-the-balkan-countries/ [Accessed 9th May 2021].

70. Richter, Solveig (2012) Two at one blow? The EU and its quest for security and democracy by political conditionality in the Western Balkans. Democratization, vol. 19, no. 3, pp. 507-534.

71. Rossos, Andrew (2008) Macedonia and the Macedonians: A History. Stanford, Hoover Institution Press. 
72. Rosůlek, Přemysl (2011) Macedonia in 2011 - on the way towards stabilization or before the new 'grand' agreement? In: Risteska, Marija \& Daskalovski, Zhidas (eds.) One Decade after the Ohrid Framework Agreement: Lessons (to be) Learned from the Macedonian Experience. Skopje, Friedrich Ebert Stiftung, Center for Research and Policy Making, pp. 66-85.

73. Rynning, Sten (2005) Return of the jedi: realism and the study of the European Union. Politique européenne, 17 (3), 10-33.

74. Rynning, Sten (2011) Realism and the Common Security and Defence Policy. Journal of Common Market Studies, 49 (1), 23-42.

75. Saveska, Suzana \& Brown, Rob (1999) 'Unemployment in the Republic of Macedonia: Policy Options for Employment Growth', paper presented at the 7th NISPAcee Annual Conference "Improving Relations between the Administration and the Public", Sofia, Bulgaria, 25-27 March.

76. Schweller, Randall L. (1994) Bandwagoning for Profit: Bringing the Revisionist State Back In. International Security, vol. 19, no. 1, pp. 72-107.

77. Sela, Ziadin (2019) North Macedonia's extortion scandal - an EU rule of law mission to end state capture. [0nline] Available from: https://www.neweurope.eu/article/north-macedonias-extortion-scandal-an-eu-rule-of-law-mission-to-end-state-capture/ [Accessed 9th May 2021].

78. Siljanovska-Davkova, Gordana (2013) Political Parties, Values, and Democratic Consolidation. In: Ramet, Sabrina P., Listhaug, Ola \& Simkus, Albert (eds.) Civic and Uncivic Values in Macedonia: Value Transformation, Education, and Media. Palgrave Macmillan, pp. 109-133.

79. Sputnik (2015) Events in Macedonia Linked to Turkish Stream, Sanctions Stance - Lavrov. [Online] Available from: https://web.archive.org/web/20201108090749/https://sputniknews.com/politics/201505151022169894/ [Accessed 8th May 2021].

80. Stambolieva, Marija (2013) Welfare and Democratization-Comparing Croatia, Serbia and Macedonia. Social Policy \& Administration, vol. 47, no. 2, pp. 142-160.

81. Stamouli, Nektaria (2020) North Macedonia gets new government. [Online] Available from: https://www.politico.eu/article/north-macedonia-gets-new-government/ [Accessed 9th May 2021].

82. Stamouli, Nektaria (2021) Western Balkans goes east for coronavirus vaccines. [Online] Available from: https://www.politico.eu/article/serbia-vaccination-coronavirus-sinopharm-china-eu/ [Accessed 9th May 2021].

83. Statista (2021) Coronavirus (COVID-19) deaths worldwide per one million population as of May 7,2021, by country. [Online] Available from: https://www.statista.com/statistics/1104709/ coronavirus-deaths-worldwide-per-million-inhabitants/ [Accessed 9th May 2021].

84. Stavrevska, Elena B. (2015a) Casino Macedonia: of spies, traitors, and patriots. [Online] Available from: https://www.opendemocracy.net/en/can-europe-make-it/casino-macedonia-of-spies-traitors-and-patriots/ [Accessed 8th May 2021].

85. Stavreska, Elena B. (2015b) Macedonia: anatomy of a crisis. [Online] Available from: https:// www.opendemocracy.net/en/can-europe-make-it/macedonia-anatomy-of-crisis/ [Accessed 8th May 2021].

86. Szpala, Marta (2016) Macedonia: a superficial democracy in the shadow of crises. [Online] Available from: https://www.osw.waw.pl/en/publikacje/osw-commentary/2016-04-01/ macedonia-a-superficial-democracy-shadow-crises [Accessed 8th May 2021]. 
87. Unkovski-Korica, Vladimir (2018) Defeat for EU and NATO expansion: the failed referendum in Macedonia. [Online] Available from: https://www.criticatac.ro/lefteast/defeat-for-euand-nato-expansion-the-failed-referendum-in-macedonia/ [Accessed 8th May 2021].

88. Vankovska, Biljana (2012) The Procrustean Bed of the State Building in the Republic of Macedonia (1991-2011). In: Daskalovski, Zhidas \& Risteska, Marija (eds.) The Macedonian Question: 20 Years of Political Struggle into European Integration Structures. Rangendingen, LIBERTAS, Skopje, Center for Research and Policy Making (CRPM), pp. 8-26.

89. Vankovska, Biljana (2013) Constitutional Engineering and Institution-Building in the Republic of Macedonia (1991-2011). In: Ramet, Sabrina P., Listhaug, Ola \& Simkus, Albert (eds.) Civic and Uncivic Values in Macedonia: Value Transformation, Education, and Media. Palgrave Macmillan, pp. 87-108.

90. Vankovska, Biljana (2014) The Echo of the Ukrainian Crisis in Macedonia. Südosteuropa, vol. 62, no. 2, pp. 221-237.

91. Vankovska, Biljana (2018) Still there 25 years later: The dispute about Macedonia's name. [Online] Available from: https://transnational.live/2018/01/11/still-there-25-years-laterthe-dispute-about-macedonias-name/ [Accessed 8th May 2021].

92. Vankovska, Biljana (2019a) A Diplomatic Fairytale or Geopolitics as Usual: A Critical Perspective on the Agreement between Athens and Skopje. In: Institute for Peace Research and Security Policy at the University of Hamburg/ IFSH (ed.) OSCE Yearbook 2018. Baden-Baden, Nomos Verlagsgesellschaft, pp. 113-134.

93. Vankovska, Biljana (2019b) 'fool's gold': the Macedonian journey from stabilitocracy to radicalization and back. Perspectives Southeast Europe, no. 7, pp. 69-74.

94. Vankovska, Biljana (2020) Geopolitics of the Prespa Agreement: Background and After-Effects. Journal of Balkan and Near Eastern Studies, vol. 22, no. 3, pp. 343-371.

95. Vasilev, George (2011) EU Conditionality and Ethnic Coexistence in the Balkans: Macedonia and Bosnia in a Comparative Perspective. Ethnopolitics, vol. 10, no. 1, pp. 51-76.

96. Walt, Stephen M. (1987) The Origins of Alliances. Ithaca, London, Cornell University Press.

97. Walt, Stephen M. (2009) Alliances in a Unipolar World. World Politics, vol. 61, no. 1, pp. 86-120.

98. Waters, Adrian (2020) Of 'Bombs' and Hybrid Regimes: How the Macedonian Colourful Revolution went full circle. [Online] Available from: https://www.institutegreatereurope. com/post/2020/07/15/of-bombs-and-hybrid-regimes-how-the-macedonian-colourfulrevolution-went-full-circle [Accessed 7th May 2021].

99. Waters, Adrian (2021) How nationalism undermines EU enlargement and values: the Macedonia-Bulgaria controversy. [Online] Available at: https://www.institutegreatereurope. com/single-post/how-nationalism-undermines-eu-enlargement-and-values-the-macedonia-bulgaria-controversy [Accessed 7th May 2021].

100. Wydra, Doris (2020) Between Normative Visions and Pragmatic Possibilities: The EUropean Politics of State Recognition. Geopolitics, vol. 25, no. 2, pp. 315-345. 